\title{
Changes of architecture expressions on Lanting House based on activity system on the river
}

\author{
Dahliani $^{1}$, Muhammad Faqih ${ }^{2}$, Arina Hayati ${ }^{2}$, \\ ${ }^{1}$ Lambung Mangkurat University, Banjarmasin, Indonesia, Doctoral Student Department of Architecture, Institut of Technology Sepuluh \\ Nopember, Surabaya, Indonesia \\ ${ }^{2}$ Department of Architecture, Institute of Technology Sepuluh Nopember, Surabaya, Indonesia
}

Email address:

lily.unlambjm@gmail.com (Dahliani), faqih@arch.its.ac.id (M. Faqih), arina.hayati@gmail.com (A. Hayati)

\section{To cite this article:}

Dahliani, Muhammad Faqih, Arina Hayati. Changes of Architecture Expressions on Lanting House Based on Activity System on the River. History Research. Vol. 3, No. 1, 2015, pp. 1-8. doi: 10.11648/j.history.20150301.11

\begin{abstract}
Lanting house is a traditional house from Banjar, South Borneo, Indonesia. It floats on the river as an expression of Banjarese culture adapted to the river. In the past, lanting house grew simultaneously with the growth of river transportation. Nowadays, settlements develop more on land, and the river transportation started to be declined. This affected the lanting houses; especially examined from the activity system, the significance of river by its inhabitants changed lanting house expression. Using qualitative approach, this research aims to find the changes in architectural expression in Lanting House based on the phenomena found. Results shows that most room layouts and buildings frontage are not oriented towards the river anymore. Elements that supports activities connected to the river is also gone, this is because essential activity of the river like river transportation is long gone.
\end{abstract}

Keywords: Change of Expression, Lanting House, Activity System, River

\section{Introduction}

Rivers in Banjarmasin have major role and function in the live hood of the people. Daily activities involve and use the river that creates river culture. The river culture means that the way of life, behavior, and adaptation of the people to live are influenced by the river for many generations (Nurfansyah, 2006). One type of Banjarese traditional houses which demonstrate riverside culture is the lanting house. From eleven types of Banjarese traditional houses (Seman and Irhamna, 2001), lanting house is the only type constructed floating on water. Factors like local natural condition, available natural resources, human resources and local culture, influenced housing that adapts to the environment (Sunarningsih, 2002). Floating lanting house adapted to the local environment that is flexible to the changes of water level as the form of Banjarese culture.

However, the existence of lanting house is decreasing with the changes of time (Mentayani, 2007). The habit of using lanting house along Martapura River (main river in Banjarmasin) is starting to disappear because of the growth of the city. Kusliansyah (2011) stated that physically-spatially Banjarmasin transformed from a water city to land city and its development. This changed the river culture to land culture.

Physically, the form of culture can be seen from the work made by the people (Koentjaraningrat, 1985). Lanting house is the physical form of Banjarese river culture; now it also experiences changes. Change in lanting house is formed by building expression to identify the importance of river as house location. Consequently, there is the need to identify the architectural expression on lanting house concerning the significance influence of river to its inhabitants. To explore lanting house expression according to Rapoport's theory (2005), the shape of built environment (in this case lanting house) can be examined more specifically using activity system and system of setting.

\section{Literature Review}

\subsection{Culture and Built Environment Concept}

Culture is close in relation to built environment as they both are man-made. Built environment as part of culture is formed by the people's personality, culture and way of thinking and doing which were shown in their activities (Daeng, 2008). 
According to Altman and Chemer (1984), there are 5 important factors of association between culture and environment: 1) natural environment; 2) environment orientation and way of life; 3) environment cognition; 4) environment behavior; and 5) environment as final product. These 5 factors are interconnected to show the relation between culture and built environment.

Culture can be seen in a form of complex activities of the people (Koentjarningrat, 1985). Culture is very broad; one small part of culture is man-made physical environment. According to Rapoport (2005), culture can be seen from conceptualizing built environment such as: 1) arrangement of room, time, meaning, and communication; 2) background system; 3) cultural landscape; 4) configuration of permanent elements (infrastructure, building, wall, floor, ceiling, roof, foundation, etc), semi permanent elements (building, interior and exterior finishings), and nonpermanent elements (humans and their activities, behaviors, clothings, vehicles, and also animals and plants).

To understand culture in built environment more easily, Rapoport (2001, 2005) dismantled culture vertically and horizontally. Vertically, culture can be elaborated into tangible social expression with potential for observations; this includes kinship, family structure, social role, social network, status, identity, institutional, etc. Horizontally, culture can be explained into life philosophy such as values. These values are divided into two, first is about ideals, images, scheme, meaning, etc; second is about way of life and activity system.

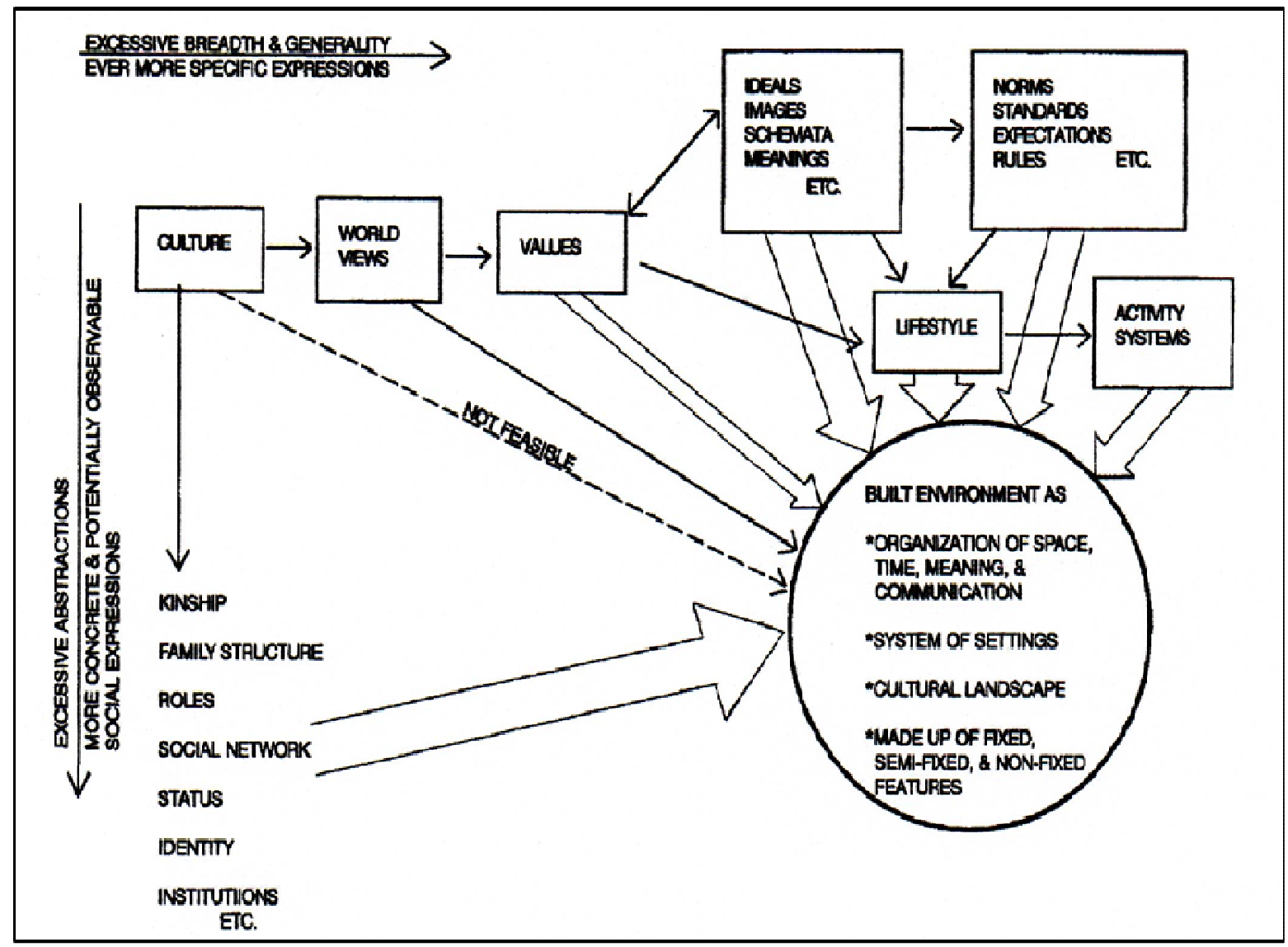

Figure 1. Dismantling of "culture” and relating its expressions to built environment

Source: Rapoport, 2001

\subsection{Architecture Expression}

According to Surasetja (2007), the expression of building shapes is influenced by three aspects: function, structure, and culture. However, Muchammad (2010) argues that expression in architecture includes three components: message, media, and receiver. Message is seen as architectural practice and knowledge is design. Media is the outcome of architecture such as building, (including shape of building, such as façade, envelope, etc; space and its components such as roof, wall, floor, etc). Receiver means the response the viewer gave to architecture design, it can be measured by design quality and building performance. Receiver is the dweller/inhabitant or community that can see that building.

\subsection{Changes in Housing}

Housing is not static, it is dynamic, and it evolves with changes of time. Housing as a place for daily activities, is adjusted to fulfill the human needs. It illustrates current behaviors, culture and way of life. Wulandari (2010) explained the main factor of changes is the expansion of accessibility in surroundings (circulation and streets), and the effects of modernization in globalization.

Changes in housing include change in construction, 
materials, shape and room layout. These were done to satisfy the inhabitants' needs and wants; to improve their life quality (Ariffudin, 2009). According to Lang in Supriyanto (2000), changes in housing occurred by 2 factors: life requirements and transformation of its surroundings. Daeng (2008) stated that activities influenced room requirements, whereas culture values influenced use of room.

\section{Research Method}

To identify the changes of architectural expression on lanting house based on activity system on the river, the research method used is qualitative descriptive. By using this method it is expected to find the natural phenomenon of the changes that happened.

Area of research is lanting houses along Martapura River, Seberang Mesjid area, Banjarmasin, South Borneo, Indonesia. Martapura River is a river that flows in downtown of Banjarmasin. There are still 10 lanting houses in this area. Field surveys are taken to collect data the room layout, frontage, construction, and materiality. Observation includes sketches and documentation, also doing in-depth interviews with inhabitants about the changes in lanting house expression in relation to activities on the river. Data collected are analyzed qualitatively to find clear understanding about changes of lanting house expression.

\section{Result and Discussion}

\subsection{River Culture and Lanting House Expression}

The existence of lanting house in Banjarmasin started from early $19^{\text {th }}$ century. The development of lanting house came from 3 ways:

- Banjarese community needs a moveable housing to accommodate their occupation as wood gatherer in the woods. Lanting house is portable, it can be moved according to their place of job (Mentayani, 2007).

- River is the main transportation mode. To fulfill the needs of the ships and boats, the people sell their products by the river; they use lanting to get near their customers. Here, lanting also functions as shop/store (Dahliani, 2006).

- New settlers from Hulu Sungai (Nagara), well-known as a community that trades using the river. This new settlers brought their lanting house and settled in places they considered preferable to live and trade (Dahliani, 2006)

According to Muchammad (2010), lanting house expression can be analyzed from the layout plan, building frontage, construction and materiality. Building expression is related to inhabitants' activity system towards the river.

\subsubsection{Room Layout (Plan)}

Lanting house has a simple rectangular room layout, positioned lengthwise to the river to minimize water current effects on building structure. Lanting house size is about $4 \times 6 \mathrm{~m}$ to $4 \times 7 \mathrm{~m}$. The size is not big because of the bamboo foundation bearing load.

In this research, the house plans are separated into 3 types according to the house orientation to the river:

1. Room Layout I (Figure 2);

Made up of 3 main rooms: living room, bedroom, and kitchen; faces the river and the land, has access to both sides; existence of deck which faces the river and land, the one that faces the river functions as bathing area while the other faces land as washing area. In this type of layout, living room is multifunction with access to both river and land.

2. Room Layout II (Figure 3);

Similar to Room Layout I, this type is made up of 3 main rooms: living room, bedroom and kitchen; originally this type faces both river and land, but the river access is closed as it was not needed; deck is found both on the river and land side, but the one on the river side is only used occasionally. Access to the river side is closed to function as bedroom and kitchen.

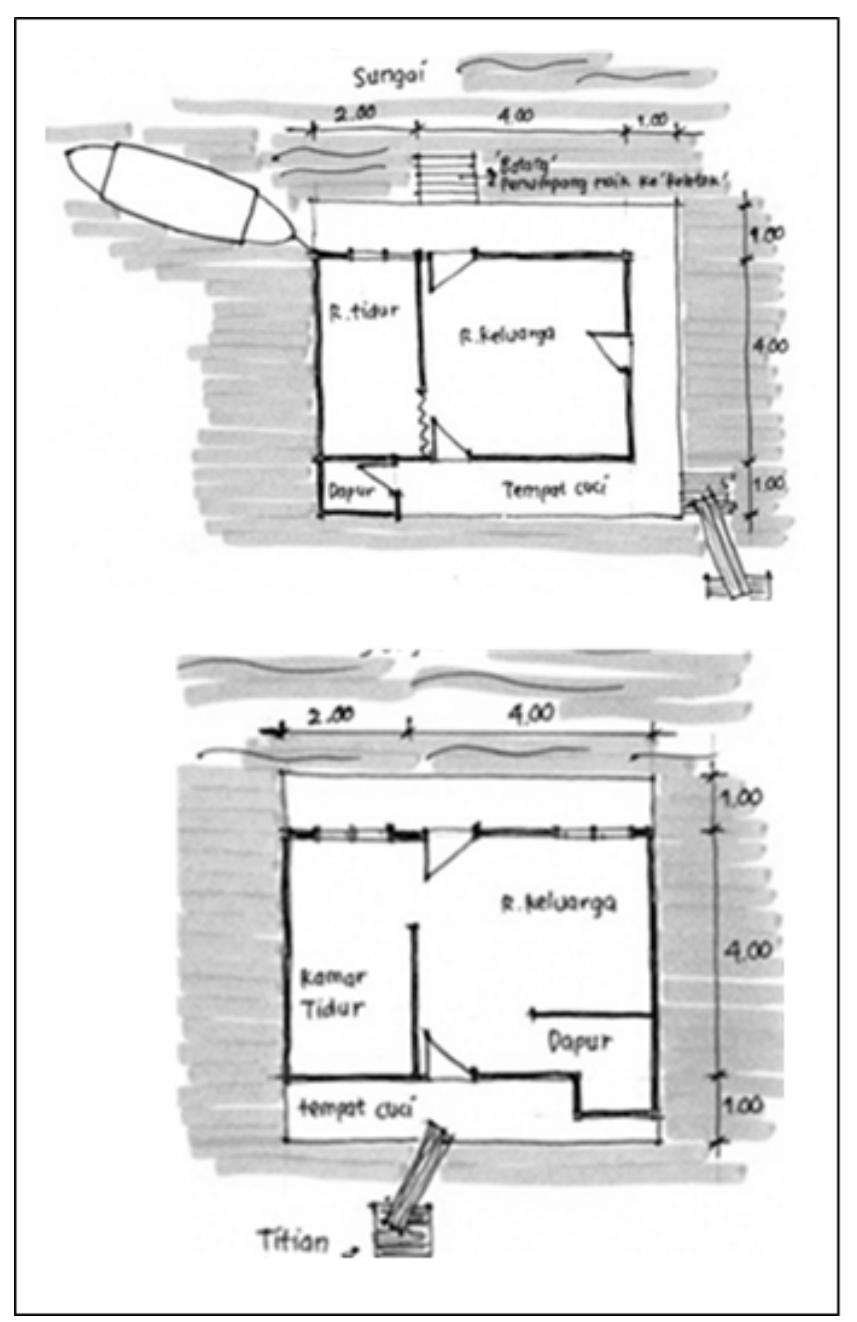

Figure 2. Lanting house Room Layout I.

Source: field data, 2014 


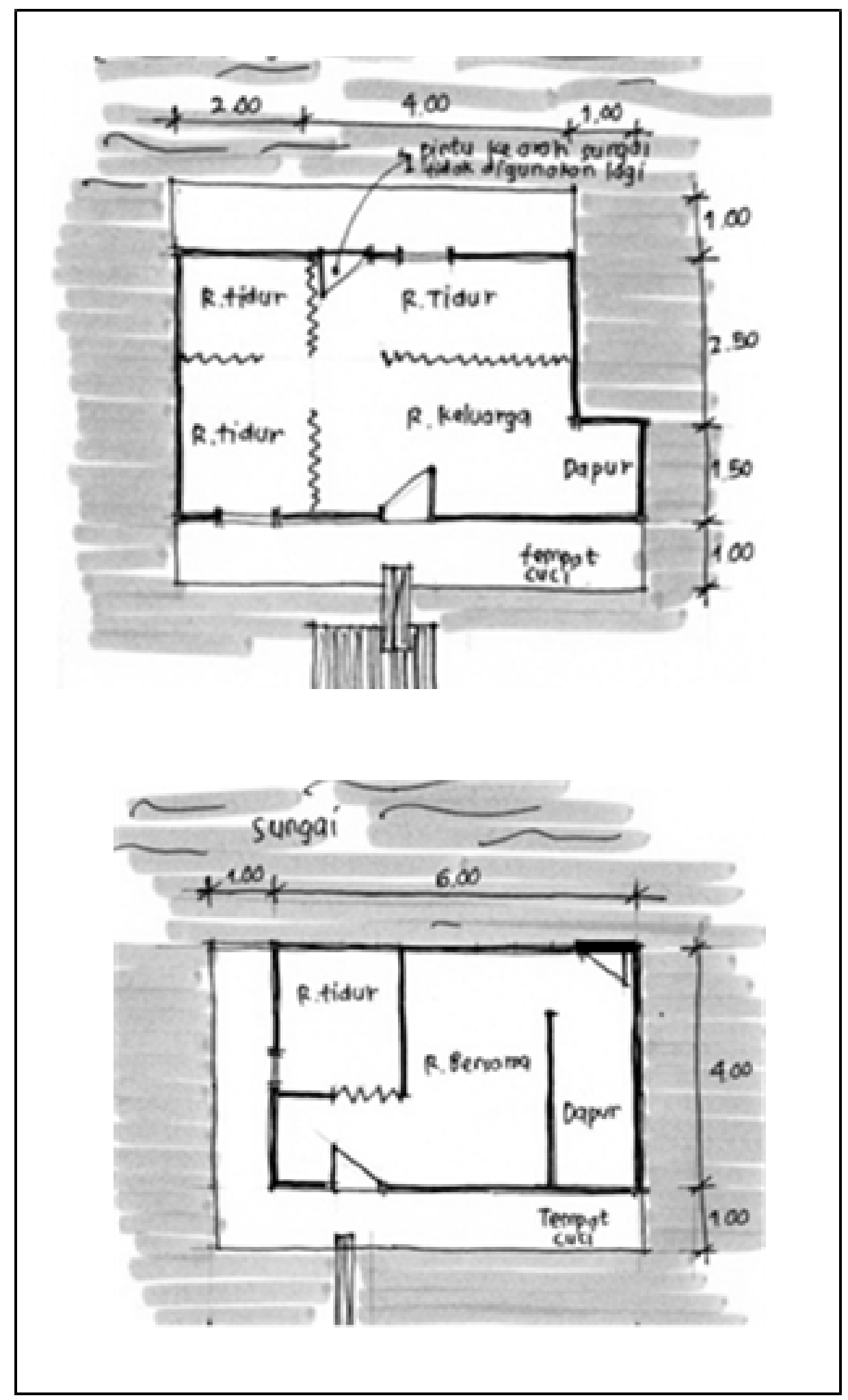

Figure 3. Lanting house Room Layout II.

Source: field data, 2014

3. Room Layout III (Figure 4);

Similar to Room Layout I and II, this type is also made up of 3 main rooms: living room, bedroom, and kitchen; there is no river orientation nor river access; deck is found on land side; washing area is at the deck which faces land; there is bathroom/WC linked to the building. 


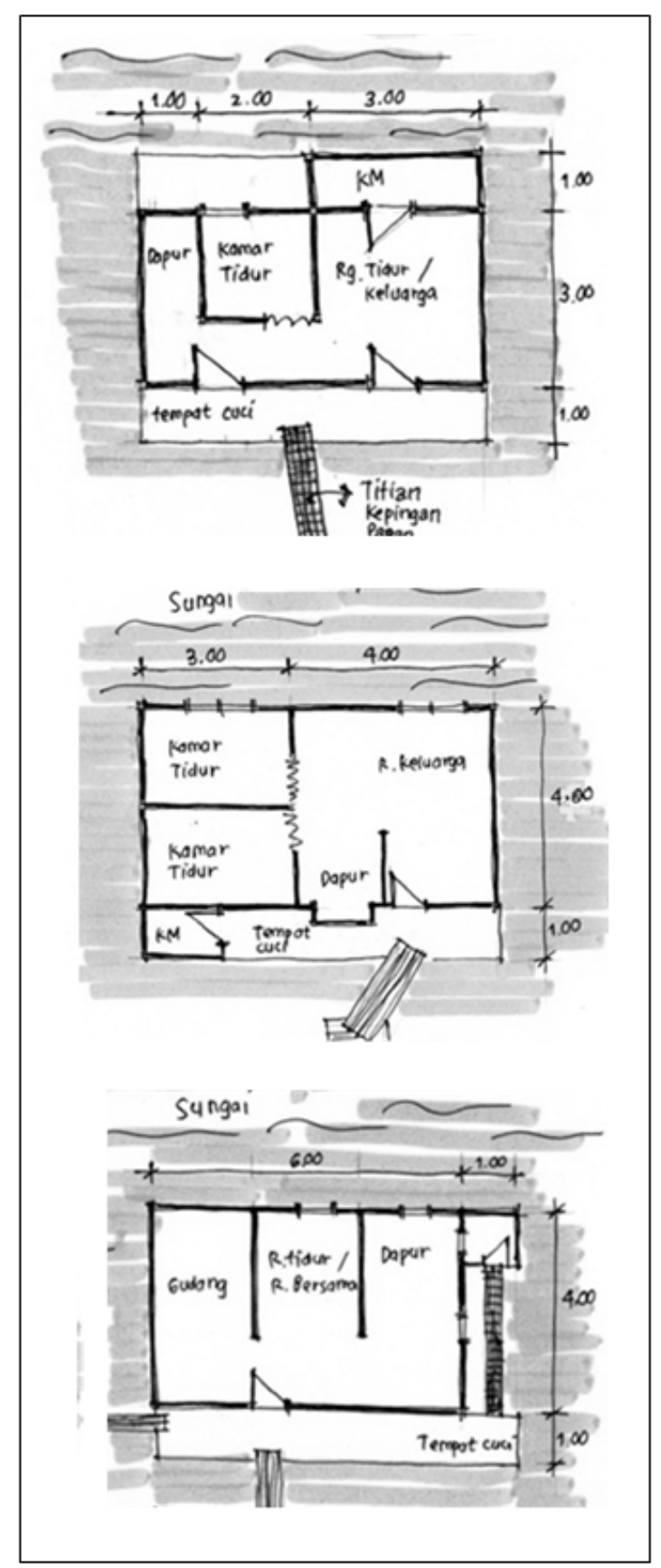

Figure 4. Lanting house Room Layout III.

Source: field data, 2014

\subsubsection{Building Frontage}

According to Surasetja (2007), building expression can be influenced by 3 aspects: function, structure, and culture. On lanting house, functional building expression is found on the tires arrangement near the foundation that faces the river. These tires are part of the additional building's facade; its function is to avoid the building structure from water currents, and mainly to minimize impact if boat/ship/kelotok stopped by. The existence of tires showed the cultural aspect on the building frontage, it shows the river is still used as mode of transportation. Other than the tires, the river culture influence can be seen by the access/door that faces the river. These 2 elements showed the existence of activity that connects with the river (Figure 5)
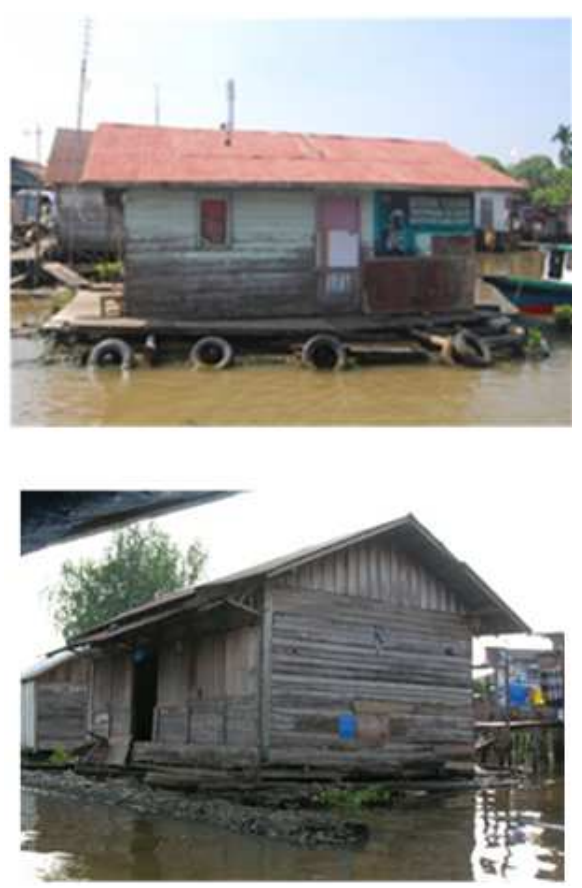

Figure 5. Lanting house frontage from the river.

Source: Personal documentation, 2014

\subsubsection{Construction and Materiality}

Lanting house expression is also influenced by structure system (construction and materiality). Construction and materiality can explained as followed:

Foundation can be made of wooden log, bamboo, or GIV pipe.

- Bamboo; 100 bamboo sticks are tied together; each bundle is linked using pegs to each floor beam. There is 1 bundle of bamboo per 1 meter width of house. The bamboo foundation is changed once every 3 years to avoid decay.

- Wooden log; each log is about $1 \mathrm{~m}$ in diameter, but since 1990s this kind of log is harder to find so it is switched to bamboo. Existing lanting houses that still use logs are leftover from the past.

- GIV pipe; it is made of metal with $80-100 \mathrm{~cm}$ diameter, welded together including partitions; this type is the newer innovation of floating foundation.

Floor beam is from iron wood (Eusideroxylon zwageri) with apron 5/10 and floor beam 5/7. Flooring is from iron wood planks for the deck and lanan wood planks for inside. Column is from iron wood 6/8 at corners of the building and every $2-3 \mathrm{~m}$ width. Wall is made of lanan wood horizontally placed, and plywood for interior partition. Roof structure is from lanan wood $6 / 8$ for roof truss and purlin, $5 / 7$ for common rafters and $3 / 5$ for roof battens. Roof cover is from corrugated zinc or sago palm leaves (rumbia).

Lanting house is a simple square building with gable roof. This simple shape and roof is to accommodate the foundation load bearing capacity. Materials used are also lightweight to 
ensure the light load for the foundation, to make it easier to float.

\subsection{Activity System Influence to Changes in Lanting House Expression}

Culture is dynamic, not static. Changes in culture will influence building expression, including room layout (plan), building frontage, construction and materiality. Activity system is specific in cultural expression; it derived from way of life. According to "dismantling culture" (Rapoport, 2005), activity system is the most concrete of cultural expression.
Main aspects of activity system are function and meaning. Changes in lanting house expression according to activity system can be explained as followed:

\subsubsection{Plan in Lanting House}

Daeng (2008) stated that activities influenced room requirement, whereas culture values influenced the use of room. Lanting house encountered changes because the inhabitants' activities changed and developed through time. Room requirements also change to accommodate those activities.

Table 1. Changes in house plan of lanting house expression

\begin{tabular}{|c|c|}
\hline & \\
\hline $\begin{array}{l}\text { Function } \\
\text { Historically, lanting house is functioned as floating shop on the river to } \\
\text { support the busy water transportation. A few is functioned as both shop } \\
\text { and home. As a shop, there was no partition in the plan. If the house is } \\
\text { functioned as a shop and home, it is separated into } 2 \text { main rooms: the } \\
\text { store and the living space was multifunctional for living, sleeping, } \\
\text { eating and cooking. }\end{array}$ & $\begin{array}{l}\text { Function } \\
\text { Further development, lanting house was used only for living, not used as double } \\
\text { function as shop and home. This was influenced by modernization of globalization } \\
\text { with the development of road travels; river transportation was slowly abandoned. } \\
\text { With the change of function, there was also a change in house plan to accommodate } \\
\text { the activities; lanting house was separated into living room (multifunction), } \\
\text { bedroom, and kitchen. }\end{array}$ \\
\hline $\begin{array}{l}\text { Meaning } \\
\text { With the busy river transportation at this era, lanting house dominantly } \\
\text { faced the river, the main access had wide opening towards the river. } \\
\text { River had big meaning to the inhabitants of lanting, not only as } \\
\text { transportation but also other activities that was related to the river. } \\
\text { Access and deck that faced the river had big meaning to the inhabitants. } \\
\text { They used it for daily activities such as 'parking the boat, calling water } \\
\text { taxi, buying daily need from passing vendors/sellers, bathe, wash, etc. }\end{array}$ & $\begin{array}{l}\text { Present Condition } \\
\text { Meaning } \\
\text { In current condition, river has meant less to the lanting inhabitants. This was due to } \\
\text { the increase of land transportation and the decrease of river transportation. As seen } \\
\text { from the house plans, access to the river is closed or not built at all. The deck facing } \\
\text { the river is also gone. } \\
\text { There are } 3 \text { patterns of changes with the river-facing deck: } \\
\text { Deck is still existed but unused because the access is closed off. } \\
\text { Deck previously is existed, but the function is changed into bathroom/WC with } \\
\text { new built massive walls. This also meant no connection to the river. } \\
\text { River-facing deck was eliminated altogether during house renovation as it was } \\
\text { considered not needed by the inhabitants. }\end{array}$ \\
\hline
\end{tabular}

Source: Analisis, 2014

Other than the changes in function and meaning above, there is one room that still maintains its original function. All lanting inhabitants still use the land-facing deck as washing area. This washing area shows that the river culture (bathe, wash, etc) is still existed. Washing area at the land-facing terrace showed that previously land was considered as back of house, whereas river is front of house.

\subsubsection{Building Frontage}

Table 2. Changes in building frontage of lanting house expression

\begin{tabular}{|c|c|}
\hline Past Condition & Present Condition \\
\hline $\begin{array}{l}\text { Building Orientation } \\
\text { As main transportation mode, river } \\
\text { was the building orientation. } \\
\text { Lanting house dominantly faced } \\
\text { the river. This was also influenced } \\
\text { by its function as shop. (Figure } 6 \text { ) }\end{array}$ & $\begin{array}{l}\text { Building Orientation } \\
\text { With the growth of land } \\
\text { transportation, lanting house } \\
\text { orientation was changed towards the } \\
\text { land. Shop function is non-existence. } \\
\text { A few lanting still have river } \\
\text { orientation and access, but most do } \\
\text { not have them. (Figure } 7 \mathrm{a} \text { and } 7 \mathrm{~b} \text { ) }\end{array}$ \\
\hline
\end{tabular}

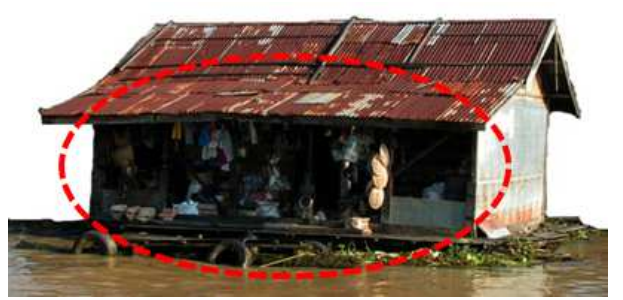

Figure 6. Building orientation in the past condition. Lanting house dominantly faced the river. This was also influenced by its function as shop

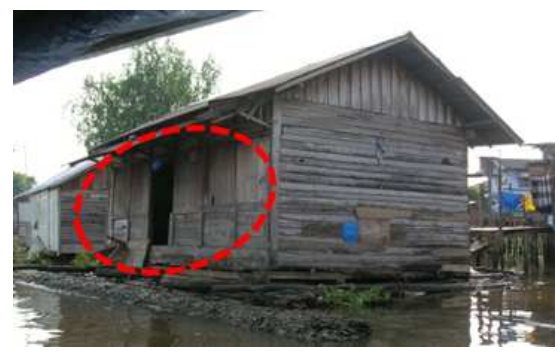

Figure 7a. Building orientation in the present condition. In the past, the lanting house function as a shop, but now is changing become a house for living only 


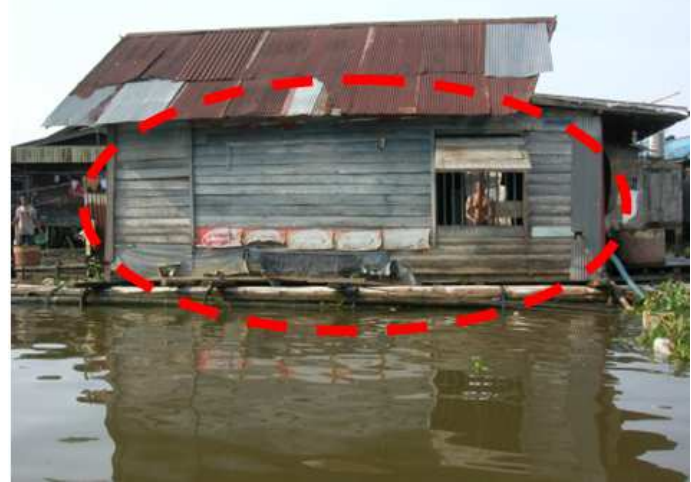

Figure $7 \boldsymbol{b}$. Building orientation in the present condition. lanting house orientation was changed towards the land. Shop function is non-existence.

Source: Personal documentation, 2014

\begin{tabular}{|c|c|}
\hline Past C & Present Condition \\
\hline $\begin{array}{l}\text { Semi-fix elements } \\
\text { Semi-fix elements as additional elements } \\
\text { to building frontage used tires } \\
\text { arrangement near river-facing foundation } \\
\text { construction. There was only } 1 \text { house that } \\
\text { still uses these tires to avoid impact from } \\
\text { boat/klotok. This house still uses tires } \\
\text { because the inhabitants' occupation is a } \\
\text { klotok driver (Figure } 8 \text { ) }\end{array}$ & $\begin{array}{l}\text { Semi-fix elements } \\
\text { Semi-fix elements such as } \\
\text { tires arrangement is no longer } \\
\text { used by most lanting houses. } \\
\text { Activities involving the river } \\
\text { significantly decrease; the } \\
\text { inhabitants considered the } \\
\text { tires are no longer needed as } \\
\text { element on their lanting house } \\
\text { (Figure 9) }\end{array}$ \\
\hline
\end{tabular}

Source: Analisis, 2014

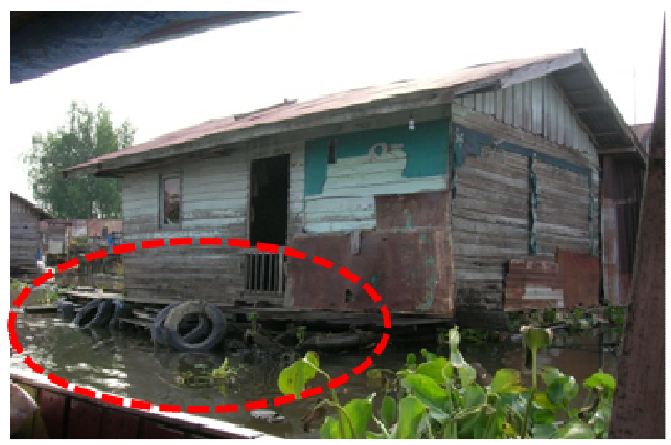

Figure 8. Semi-Fix element in the past condition. Semi-fix elements as additional elements to building frontage used tires arrangement near river-facing foundation construction

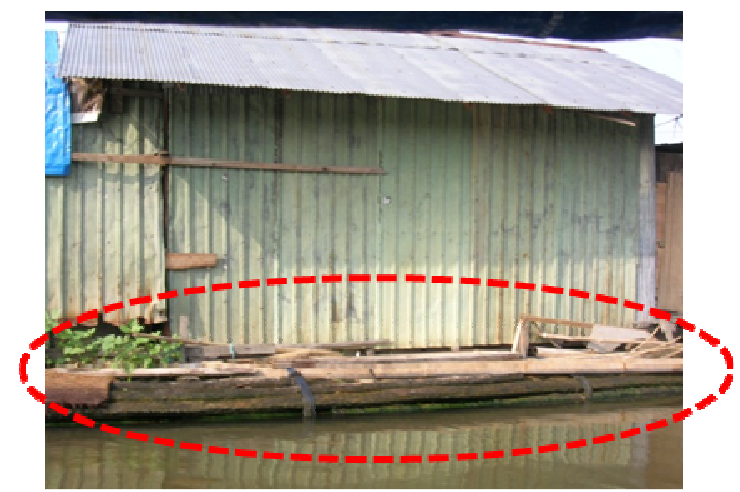

Figure 9. Semi-fix element in the present condition. Semi-fix elements such as tires arrangement is no longer used by most lanting houses.

Source: Personal documentation, 2014

\subsubsection{Construction and Materiality}

Changes in lanting house expression for construction and materiality are found on the foundation material.

Table 3. Changes in construction and materiality of lanting house expression

\begin{tabular}{|c|c|}
\hline Pas & Present Condition \\
\hline \multirow{12}{*}{$\begin{array}{l}\text { Foundation } \\
\text { Wooden log with } 1 \mathrm{~m} \\
\text { diameter was still } \\
\text { easily found in } \\
\text { Kalimantan. Using this } \\
\text { log, lanting house } \\
\text { dimension can be made } \\
\text { longer because of the } \\
\text { strong load bearing } \\
\text { capacity. }\end{array}$} & Jundation \\
\hline & long gone. \\
\hline & \\
\hline & beside \\
\hline & Hew 10 a \\
\hline & The const \\
\hline & as foundation, \\
\hline & -150 bamboo. \\
\hline & use din \\
\hline & \\
\hline & $\begin{array}{l}\text { One weakness for this type of foundation, in } \\
\text { every } 2 \text { years it is needed to be renewed. This is }\end{array}$ \\
\hline & $\begin{array}{l}\text { a complication for the inhabitants, they need } \\
\text { regular maintenance cost to repair the foundation } \\
\text { to keep their house floating (Figure 10) }\end{array}$ \\
\hline
\end{tabular}

Source: Analisis, 2014

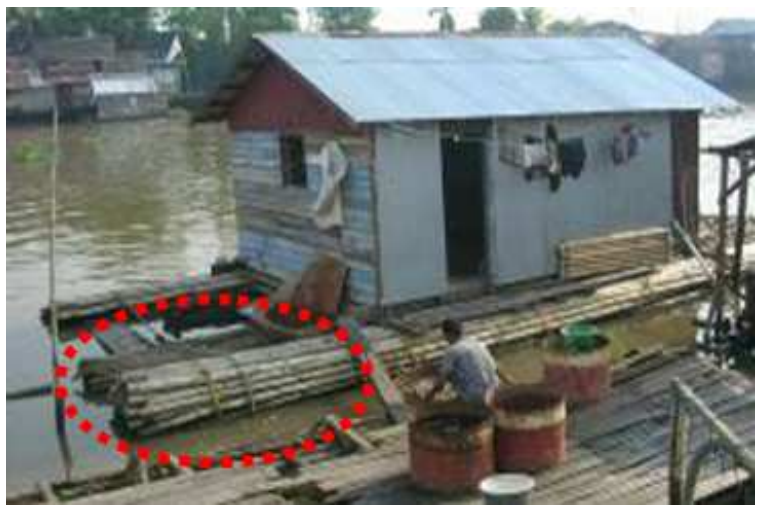

Figure 10. Foundation Construction in present condition is using bamboo

Source: Personal documentation, 2014

The construction of lanting house can see in figure 11.

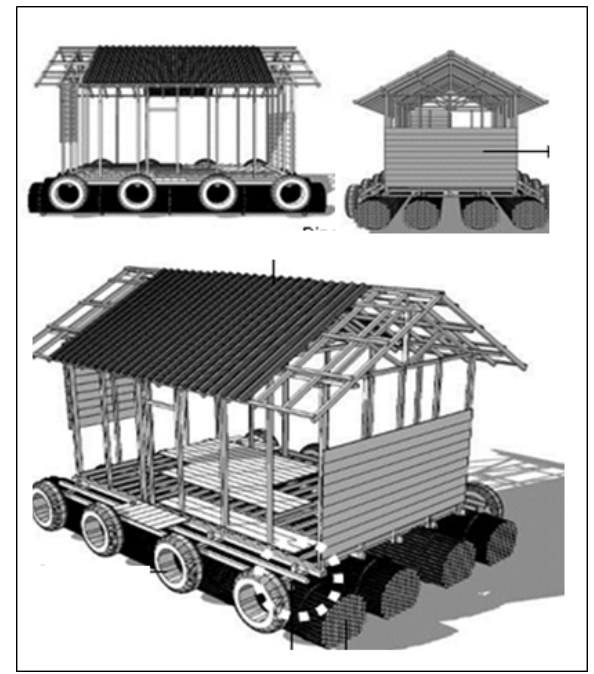

Figure 11. The construction of lanting house

Source: Dahliani, 2013 


\section{Conclusion}

Changes in building expression can be seen from specific culture expression which is activity system. Activity system of lanting house is connected with its site on the river. Changes in expression can be found in room layout (house plan), building frontage, construction and materiality.

- There was change in function and meaning of the building concerning river transportation activities; this changed the lanting house expression with its room layout.

- There was change in building frontage as building orientation and access changed from the river to land; it showed a change in river system activity.

- There was change in usage of construction material that can float on water with the shortage of wooden logs; this influenced the change in house dimension.

- The changes in lanting house is according with Daeng's theory which stated that activities influenced room requirements, whereas culture values influenced use of room. The dimensions of lanting house did not have a significant change, but the space inside which undergo changes with a clearer division of space to meet the inhabitants activity.

\section{References}

[1] Altman dan Chemers 1984. Culture and Environment. Brook/Cole Publishing Company. California

[2] Daeng, Hans. 2008. Manusia, Kebudayaan dan Lingkungan, Tinjauan Antropologis. Pustaka Pelajar. Yogyakarta

[3] Dahliani, 2006, Revitalisasi Permukiman Di Kawasan Mesjid Sultan Suriansyah Kelurahan Kuin Utara, Banjarmasin, Thesis, Institut Teknologi Sepuluh Nopember, Surabaya

[4] Dahliani. 2013. Rumah Lanting : Bangunan yang Adaptif pada Tapak Permukiman Tepian Sungai, Banjarmasin. Prosiding
Semesta Arsitektur Nusantara 2 Arsitektur Nusantara Berkelanjutan. Universitas Brawijaya. Malang

[5] Koentjaraningrat. 1985. Kebudayaan, Mentalitas dan Pembangunan. PT. Gramedia. Jakarta

[6] Kusliansjah, Karyadi 2001. Transformasi Arsitektur Kota Pada Elemen Kanal Kota Banjarmasin - Kalimantan Selatan. Research Report - Engineering Science Volume 2 tahun 2011. Univ. Parahiyangan

[7] Mentayani, Ira. 2007. Tipomorfologi Arsitektur Rumah di Atas Air (Lanting) di Kalimantan Selatan. Laporan Penelitian. Lembaga Penelitian. Universiitas Lambung Mangkurat. Banjarmasin

[8] Nurfansyah. 2006. Pola Permukiman dan Orientasi Bangunan di Tepi Sungai Jingah. Proceedings Seminar Arsitektur 2006 : Permukiman Tepi Sungai Problema dan Solusinya. Program Studi Arsitektur. Universitas Lambung Mangkurat. Banjarmasin.

[9] Rapoport, Amos. 2001. Theory, Culture and Housing. Housing, Theory and Society. Taylor \& Francis

[10] Rapoport, Amos. 2005. Culture Architecture, and Design. Lock Science Publishing Company, Inc. USA

[11] Seman dan Irhamna. 2001. Arsitektur Tradisional Banjar kalimantan Selatan. Ikatan Arsitektur Indonesia Daerah Kalimantan Selatan

[12] Sunarningsih. 2002, Pola Perkampungan Tradisional Masyarakat Banjar di Tepian Sungai : Salah Satu Bentuk Adaptasi Lingkungan, Bulletin Arkeologi Naditira Widya No. 09, Pusat Penelitian Arkeologi, Banjarmasin

[13] Surasetja, Irawan. 2007. Fungsi, Ruang, Bentuk dan Ekspresi dalam Arsitektur. Program Studi Arsitektur. FPTK UPI.

[14] Muchammad, Bani Nur. 2010. Model Ekspresi Arsitektur. Seminar Nasional Metodologi Riset dalam Arsitektur

[15] Wulandari, Lisa Dwi. 2010 Proses Perubahan Ruang Spasial Di Permukiman Dusun Baran Kidal Malang. Local Wisdom-Jurnal Ilmiah Online, Volume: II, Nomor: 3, September 2010 